\title{
PELAKSANAAN PERJANJIAN ANTARA BANK PENERBIT KARTU KREDIT (ISSUER) DENGAN PEMEGANG KARTU (CARD HOLDER) DALAM PENGGUNAAN KARTU KREDIT (Studi Pada PT. Bank Rakyat Indonesia, Tbk. Cabang Padang)
}

\author{
Oleh: \\ Rinrani Patrisia \\ Email: rinranipatrisia@yahoo.com \\ Fakultas Hukum Universitas Andalas
}

\begin{abstract}
ABSTRAK
Kartu kredit merupakan suatu kebutuhan bagi masyarakat modern untuk menggunakannya sebagai alat pembayaran tunai. Dalam pelaksanaan pada PT. Bank Rakyat Indonesia (Persero) Tbk terdapat kendala-kendala yang dihadapi oleh pihak BRI yaitu ketika pemegang kartu lalai dalam penggunaan kartu kredit dan tidak melaksanakan kewajibannya dengan baik, maka penyelesaiannya pemegang kartu wajib memberikan penggantian biaya, rugi dan bunga yang telah ditentukan oleh pihak BRI cabang Padang. Sedangkan kendala-kendala yang dialami oleh pemegang kartu yaitu penambahan biaya dan proses-proses yang lama dalam hal yang menyangkut dengan kartu kredit. Berdasarkan hal diatas dapat disimpulkan bahwa pelaksanaan perjanjian penggunaan kartu kredit pada PT. BRI Tbk, cabang Padang telah sesuai dengan peraturan perundang-undangan yang berlaku, akan tetapi dalam hak dan kewajiban para pihak masih belum seimbang.
\end{abstract}

Kata kunci: kartu kredit, kelalaian, Bank BRI

\begin{abstract}
In modern era, credit card is an instrument to meet the banking customers' demands. In fact, there are some stumbling blocks which faced by PT Bank Rakyat Indonesia (Persero), shortly named Bank BRI, to provide the credit card services. One of all, the customer disregards their obligations of credit card holder. Consequently, they are fined by Bank BRI in Padang for their financial wrong-doings. On the other hand, the card holders also find some handicaps using their credit card, such as additional fees and complicated procedures in credit card service. According to data described above, the writer concludes that the credit card agreement comply with the laws. However, the writer defines that the obligations and rights between the bank and customers are not equal.
\end{abstract}

Keywords: credit card, disregard, Bank BRI 


\section{PENDAHULUAN}

Dalam rangka memenuhi kebutuhan hidupnya, manusia mengadakan transaksi satu sama lainnya. Cara dalam melakukan transaksi terus berubah seiring dengan perkembangan zaman, seperti zaman dahulu yang diawali dengan bertransaksi dengan cara tukar-menukar barang, kemudian transaksi dengan menggunakan uang, dan cara tersebut masih tetap berlangsung sampai saat sekarang. Tetapi dalam perkembangan saat ini, alat bayar uang belum cukup aman untuk dipergunakan dan juga tidak praktis untuk dibawa-bawa dalam jumlah yang banyak karena dapat mengundang kejahatan, seperti perampokan dan lainnya. Oleh karena itu, teknologi dan ilmu pengetahuan menciptakan suatu terobosan baru yang merupakan salah satu produk dari bank yang selanjutnya akan disebut sebagai kartu kredit (Credit Card).

Kartu kredit merupakan suatu kartu yang pada umumnya dibuat dari bahan plastik, dengan dibubuhkan identitas dari pemegang dan penerbitnya, yang memberikan hak terhadap siapa kartu kredit diterbitkan untuk menandatangani tanda pelunasan pembayaran dari jasa atau barang yang dibeli ditempat-tempat tertentu, seperti toko, hotel, restaurant, penjual tiket pengangkutan dan lain-lain. ${ }^{1}$

Pada saat ini kartu kredit merupakan suatu kebutuhan bagi masyarakat modern untuk menggunakannya sebagai alat pembayaran tunai. Dengan kartu plastik tersebut nasabah dapat melakukan berbagai macam transaksi dan mereka tidak perlu datang dan antri di kantor ataupun bank pemberi jasa, mereka cukup mendatangi outlet-outlet yang tersebar hampir di seluruh tempat, utuk memenuhi transaksi yang dibutuhkan baik ambil tunai maupun pengiriman uang (Transfer) khususnya untuk transaksi pembayaran kartu kredit. Dan kartu kredit dapat dipergunakan di mana saja, dan dapat menjamin keselamatan pemegang kartu, karena tidak perlu lagi membawa uang dalam jumlah banyak, tetapi hanya perlu membawa sebuah kartu kredit yang dapat digunakan untuk pembayaran.

Kemudahan dalam kartu kredit semakin meningkat, terutama kemudahan dalam pembayarannya. Pada saat ini pengguna kartu dapat membayarkan tagihan kartu kredit hanya dengan menggunakan ponsel seluler pintar (Smartphone) maupun tablet secara nontunai. Menurut lembaga konsultan internasional, Gartner

\footnotetext{
${ }^{1}$ Munir Fuady, Hukum tentang Pembiayaan, Bandung : PT. Citra Aditya Bakti, 2006, hlm.174.
} 
Inc, pembayaran transaksi yang dilakukan secara tanpa uang tunai (Daring) pada tahun 2012 melebihi US\$ 171,5 milliar (sekitar Rp 1.663 triliun) meningkat 60\% dari tahun 2011. Dan berdasarkan survey JD Power and Associates, per Agustus 2012, 7\% pemegang kartu kredit memakai ponsel mereka untuk membayar transaksi, jumlahnya meningkat hampir dua kali lipat dibandingkan $2011^{2}$. Berarti pengguna kartu kredit semakin dimanjakan dengan fasilitas-fasilitas serta kemudahan-kemudahan kartu kredit yang semakin meningkat.

Dalam pembuatan perjanjian baku pihak penerbit atau Bank selaku pelaku usaha harus memperhatikan klausul yang dibuat agar tidak merugikan nasabah selaku konsumen. Batasan-batasan tersebut termuat dalam Pasal 18 Undangundang Nomor 8 Tahun 1999 tentang perlindungan konsumen. Menurut Irdanuraprida Idris SH.,MH, dalam perjanjian kartu kredit pada umumnya belum memenuhi keadilan bagi konsumen pemegang kartu, dapat dilihat pada klausulklausul yang dibuat dalam perjanjian tersebut yang mana hak dan kewajiban antara bank dengan pemegang kartu diatur secara mendetail, disisi lain kewajiban bank sangat sedikit, serta kebalikanya hak bank sangat banyak sedangkan hak pemegang kartu sangat sedikit. ${ }^{3}$

Dalam penggunaan kartu kredit para pihak akan menghadapi beberapa kendala. Kendala-kendala itu umumnya banyak terjadi dalam praktek penggunaan kartu kredit seperti adanya wanprestasi maupun perbuatan lainnya yang tergolong dalam pelanggaran perjanjian dalam penggunaan kartu kredit. Hal ini mengakibatkan para pihak harus berhati-hati dalam menghadapi kendala-kendala tersebut, agar tidak dapat terulang lagi. Dalam pelaksanaan proses penerbitan maupun penggunaan kartu kredit, khususnya pada PT. Bank Rakyat Indonesia (Persero) Tbk, secara umum tidak diketahui dengan detail oleh calon pengguna kartu kredit BRI.

Berdasarkan hal tersebut, penulis mencoba untuk melakukan penelitian pelaksanaan perjanjian yang di lakukan oleh para pihak dalam penggunaan kartu kredit pada PT. Bank Rakyat Indonesia Tbk, khususnya pada PT. Bank Rakyat

\footnotetext{
2 Marchelo, Media Indonesia, E-Money-“Dunia Menuju Tatanan Masyarakat Nontunai”, kamis, 21 Februari 2013, hlm. 14.

${ }^{3}$ Irdanuraprida Idris http://www.irmadevita.com diakses pada tanggal 18 Maret 2013, pukul 11:00
} 
Indonesia Tbk, cabang Padang. Maka penulis tertarik untuk membahas dan melakukan penelitian tentang perjanjian kartu kredit dengan kelengkapan pada judul "PELAKSANAAN PERJANJIAN ANTARA BANK PENERBIT KARTU KREDIT (ISSUER) DENGAN PEMEGANG KARTU (CARD HOLDER) DALAM PENGGUNAAN KARTU KREDIT (STUDI PADA PT BANK RAKYAT INDONESIA TBK, CABANG PADANG)”.

\section{RUMUSAN MASALAH}

Berdasarkan uraian latar belakang yang telah dikemukakan di atas, maka ada beberapa permasalahan yang ingin penulis ketahui jawabannya melalui penelitian:

1. Bagaimana proses penerbitan kartu kredit pada PT. Bank Rakyat Indonesia Tbk, cabang Padang ?

2. Bagaimanakah pelaksanaan hak dan kewajiban para pihak dalam penggunaan kartu kredit pada PT. Bank Rakyat Indonesia Tbk, cabang Padang?

3. Apa kendala-kendala dalam pelaksanaan perjanjian penggunaan kartu kredit dan upaya penyelesaiannya pada PT Bank Rakyat Indonesia Tbk, cabang Padang?

\section{TINJAUAN UMUM}

\section{A. Tinjauan Umum Tentang Perjanjian}

Pengertian perjanjian dalam Kitab Undang-undang Hukum Perdata (BW), terdapat dalam Pasal 1313, yaitu : "Perjanjian adalah suatu perbuatan hukum dimana satu orang atau lebih mengikatkan diri terhadap satu orang lain atau lebih".

Kata "perbuatan" yang terdapat dalam pasal 1313 KUHPerdata diatas mencakup juga perbuatan konsensus. Dalam pengertian "perbuatan" termasuk juga tindakan melaksanakan tugas tanpa kuasa (Zaakwarneming), tindakan 
melawan hukum (Onrechtmatigedaad) yang tidak mengandung konsensus. Dan juga tidak menyebutkan tujuan mengadakan perjanjian, sehingga para pihak tidak jelas mereka mengikatkan diri untuk apa.

Menurut Abdulkadir Muhammad, pengertian tersebut kurang tepat karena ada beberapa kelemahan yang perlu dikoreksi, yaitu:

1. Hanya menyangkut sepihak saja.

Hal ini dapat diketahui dari rumusan kata kerja "mengikatkan diri", sifatnya hanya datang dari satu pihak saja, tidak dari kedua belah pihak. Seharusnya rumusan itu ialah "saling mengikatkan diri", jadi ada konsensus antara dua pihak.

2. Kata "perbuatan" mencakup juga tanpa konsensus.

Dalam pengertian "perbuatan” termasuk juga tindakan penyelenggaraan kepentingan (Zaakwaarneming), tindakan melawan hukum (Onrechtmatige daad) yang tidak mengandung suatu konsensus. Seharusnya dipakai istilah "persetujuan".

3. Pengertian perjanjian terlalu luas.

Pengertian perjanjian mencakup juga perjanjian kawin yang diatur dalam bidang hukum keluarga. Padahal yang dimaksud adalah hubungan antara debitur dan kreditur mengenai harta kekayaan. Perjanjian yang diatur dalam buku III KUHPerdata sebenarnya hanya meliputi perjanjian yang bersifat kebendaan, bukan bersifat kepribadiaan.

4. Tanpa menyebutkan tujuan.

Dalam rumusan pasal 1313 KUHPerdata itu tidak disebutkan tujuan mengadakan perjanjian, sehingga pihak-pihak mengikatkan diri itu tidak jelas untuk apa. ${ }^{4}$

Dalam Buku III, Bab 11 KUHPerdata yang berjudul "perikatan-perikatan yang lahir dari perjanjian atau kontrak." Pengaturan tersebut dimulai dari Pasal 1313-1351 KUHPerdata, yang terdiri dari 4 bagian, yaitu :

1. Ketentuan-ketentuan umum mulai dari Pasal 1313-1319 KUHPerdata

\footnotetext{
${ }^{4}$ Abdul Kadir Muhammad, Hukum Perikatan, PT. Citra Aditya, Bandung, 1992 hlm. 78
} 
2. Tentang syarat-syarat yang diperlukan untuk syah nya perjanjian mulai dari Pasal 1320-1337 KUHPerdata

3. Tentang akibat perjanjian mulai dari Pasal 1338-1341 KUHPerdata

4. Tentang penafsiran perjanjian mulai dari Pasal 1342-1351 KUHPerdata, di tambah dengan :

a. Pasal 1266 dan Pasal 1267 KUHPerdata yaitu mengenai syarat putusnya perjanjian berupa wanprestasi.

b. Pasal 1446 sampai dengan Pasal 1456 KUHPerdata yaitu mengenai kebatalan dan pembatalan perikatan.

\section{B. Tinjauan Khusus Tentang Peraturan Bank Indonesia}

1. PBI Nomor 10/10/PBI/2008 Tentang Perubahan Atas Peraturan Bank Indonesia Nomor 7/7/PBI/2005 Tentang Penyelesaian Pengaduan Nasabah

Dalam Peraturan Bank Indonesia (PBI) Tentang Penyelesaian Pengaduan Nasabah Pasal 1 angka 2: "Pengertian nasabah itu sendiri ialah pihak yang menggunakan jasa Bank, termasuk pihak yang tidak memiliki rekening namun memanfaatkan jasa Bank untuk melakukan transaksi keuangan (walk-in customer)."

Pengguna atau pemegang kartu kredit (card holder) merupakan seorang nasabah, sebagaimana tercantum dalam PBI. Oleh karena itu, setiap pengaduan yang merupakan ungkapan ketidakpuasan pemegang kartu yang disebabkan oleh adanya potensi kerugian financial yang diduga karena kesalahan atau kelalaian Bank dapat diajukan secara tulisan maupun lisan kepada Bank. Pengaduan itu sendiri dapat dilakukan oleh nasabah ataupun perwakilan nasabah. Perwakilan nasabah merupakan perseorangan, lembaga dan atau badan hukum yang bertindak untuk dan atas nama Nasabah dengan berdasarkan surat kuasa khusus dari Nasabah, sesuai dengan pasal 1 angka 3 PBI tentang Penyelesaian Pengaduan Nasabah.

2. PBI Nomor 14/02/PBI/2012 Tentang Perubahan Atas PBI 11/11/PBI/2009 Tentang Penyelenggaraan Kegiatan Alat Pembayaran Dengan Menggunakan Kartu (APMK)

Alat Pembayaran Dengan Menggunakan Kartu (APMK) merupakan alat pembayaran yang berupa kartu kredit, kartu Automated Teller Machine (ATM) 
dan/atau kartu debet. Kartu kredit sendiri, merupakan salah satu alat pembayaran yang menggunakan kartu yang memiliki pengaturan khusus dalam Peraturan Bank Indonesia ini. Pengertian kartu kredit menurut pasal 1 ayat (4) dalam PBI ini yaitu: "APMK yang dapat digunakan untuk melakukan pembayaran atas kewajiban yang timbul dari suatu kegiatan ekonomi, termasuk transaksi pembelanjaan dan/atau untuk melakukan penarikan tunai, dimana kewajiban pembayaran pemegang kartu dipenuhi terlebih dahulu oleh acquirer atau penerbit, dan pemegang kartu berkewajiban untuk melakukan pembayaran pada waktu yang disepakati baik dengan pelunasan secara sekaligus (charge card) ataupun dengan pembayaran secara angsuran".

Dalam penerbitan Kartu Kredit, Bank atau Lembaga selain Bank yang merupakan pihak penerbit, wajib untuk memperoleh izin dari Bank Indonesia yang mana persyaratan dan tata cara untuk memperoleh izin tersebut telah diatur dalam Surat Edaran Bank Indonesia. Menurut pasal 16 angka 1 dalam hal penerbitan kartu kredit, penerbit berkewajiban memberikan informasi secara tertulis kepada pemegang kartu, informasi tersebut paling kurang meliputi:

a. Prosedur dan tata cara penggunaan Kartu Kredit

b. Hal-hal penting yang harus diperhatikan oleh Pemegang Kartu dalam penggunaan Kartu Kredit dan konsekuensi atau risiko yang mungkin timbul dari penggunaaan Kartu kredit

c. Hak dan kewajiban Pemegang Kartu

d. Tata cara pengajuan pengaduan atas Kartu Kredit yang diberikan dan perkiraan lamanya waktu penanganan pengaduan tersebut

e. Pola, tata cara dan komponen yang dijadikan dasar penghitungan bunga, biaya (fee) dan denda Kartu Kredit

f. Jenis biaya ( $f e e)$ dan denda yang dikenakan

g. Prosedur dan tata cara pengakhiran dan/atau penutupan fasilitas Kartu Kredit

h. Ringkasan transaksi Pemegang Kartu Kredit, berdasarkan permohonan dan/atau persetujuan Pemegang Kartu Kredit. 
Kewajiban-kewajiban tersebut harus dipenuhi oleh pihak penerbit, dan penerbit juga wajib menyampaikan perubahan informasi tersebut secara tertulis kepada pemegang kartu.

\section{HASIL PENELITIAN DAN PEMBAHASAN}

\section{A. Proses Penerbitan Kartu Kredit Pada PT. Bank Rakyat Indonesia, (Persero) Tbk. Cabang Padang}

Dalam mengajukan permohonan untuk menjadi pemegang kartu kredit BRI, pemohon diberikan formulir permohonan yang wajib diisi, yang mana pada formulir tersebut terdapat :

1. Jenis kartu kredit yang dikehendaki :

Terdapat 3 (tiga) pilihan kartu kredit yang ditawarkan pihak BRI, yaitu Kartu Standard, Kartu Gold, dan Kartu Platinum, yang mana masingmasing kartu memiliki ketentuan yang berbeda, yaitu ${ }^{5}$ :

a. Untuk Kartu Standard, harus memiliki pendapatan minimal Rp. 3.000.000,- (Tiga juta rupiah) perbulan atau Rp. 36.000.000,- (Tiga puluh enam) juta per tahun

b. Untuk Kartu Gold, harus memiliki pendapatan minimal Rp. 7.000.000,(Tujuh juta rupiah) per bulan atau Rp. 84.000.000,- (Delapan puluh empat) juta pertahun

c. Kartu Platinum, pendapatannya harus lebih dari Rp. 15.000.000,(Limabelas juta rupiah) per bulan atau Rp. 180.000.000,- (Seratus delapan puluh) juta pertahun.

\section{Data Pribadi}

Merupakan data yang mana pemohon wajib mengisi semua keterangan yang diminta dalam form aplikasi ini, data tersebut adalah :

a. Nama lengkap (sesuai KTP/Passport)

b. Nama yang dikehendaki pada Kartu

c. Jenis kelamin

d. Kewarganegaraan

${ }^{5}$ Hasil wawancara dengan Ibu Prima (Staf Bagian Kartu Kredit PT. Bank Rakyat Indonesia, Tbk, cabang Padang) tanggal 16 April 2013. 
e. Nomor KTP/Passport

f. Tempat dan tanggal lahir

g. Alamat E-mail

h. Status rumah, lama menempati, alamat rumah sekarang, beserta telepon rumah/ HP

i. Status perkawinan

j. Jumlah tanggungan

k. Pendidikan terakhir

1. Nama gadis ibu kandung sebelum menikah

3. Data keluarga terdekat yang dapat dihubungi dalam keadaan darurat (tidak serumah)

a. Nama lengkap keluarga terdekat

b. Hubungan keluarga

c. Alamat rumah sekarang, beserta telepon rumah/HP/Kantor.

4. Data pekerjaan

Merupakan data keterangan pekerjaan calon pemegang kartu kredit;

a. Nama perusahaan/ tempat bekerja

b. Alamat kantor termasuk nama gedung, serta telpon kantor dan fax kantor

c. Pekerjaan

d. Bidang usaha

e. Status pekerjaan

f. Lama bekerja

g. Pangkat/ jabatan

h. Jumlah karyawan

i. Gaji/ upah ( 1 tahun )

j. Penghasilan tambahan (1 tahun)

5. Kartu kredit yang dimiliki sekarang

Bagian ini diisi, apabila calon pemegang kartu telah memiliki kartu kredit.

a. Nama Bank

b. No. Kartu

c. Sejak bulan, tahun serta limit 
6. Informasi rekening

Diisi apabila calon pemegang kartu memiliki rekening simpanan/ pinjaman di BRI.

7. Alamat penagihan kartu

8. Kartu tambahan

9. Autodebet

Pembayaran melalui debet rekening simpanan, rekening simpanan pada Bank BRI

a. No. Rekening

b. Sebesar (jumlah pembayaran), pada bagian ini terdapat dua pilihan yaitu pembayaran minimal (Minimum Payment) dan pembayaran penuh (Full Payment).

10. BRI Protection Plus

BRI Protection Plus merupakan asuransi yang ditawarkan oleh BRI untuk pemegang kartu kredit, yang mana isi dari klausulanya adalah :

"Saya menginginkan fasilitas perlindungan dari BRI Protection Plus dan saya menyatakan bahwa saat ini saya berumur dibawah 61 tahun. Saya tidak pernah menderita atau dalam perawatan medis apapun karena kanker, tumor, gangguan pada jantung, tekanan darah tinggi, stroke, penyakit hati (liver), penyakit ginjal, atau terinfeksi HIV". "Saya menyetujui premi yang harus saya bayarkan dibebankan pada kartu kredit BRI saya”.

Berdasarkan Pasal 38 ayat (1) PBI Nomor 14/02/PBI/2012 tentang Penyelenggaraan Kegiatan APMK menyatakan bahwa : "Prinsipal, Penerbit, Acquirer, Penyelenggara Kliring, dan/atau Penyelenggara Penyelesaian Akhir yang melanggar ketentuan dalam Pasal 3, Pasal 4, Pasal 8, Pasal 10, Pasal 12, Pasal 13, Pasal 14, Pasal 15, Pasal 15A, Pasal 16, Pasal 16A, Pasal 16B, Pasal 17, Pasal 17A, Pasal 17B, Pasal 18, Pasal 19, Pasal 21, Pasal 22, Pasal 23, Pasal 25, Pasal 26, Pasal 27, Pasal 29, Pasal 29A, Pasal 32, Pasal 33, Pasal 34, Pasal 35, Pasal 56, Pasal 57, Pasal 58, Pasal 58B dikenakan sanksi administratif berupa: 

a. teguran
b. denda
c. penghentian sementara sebagian atau seluruh kegiatan APMK; dan/atau
d. pencabutan izin penyelenggaraan kegiatan APMK.

Hal ini berarti, pihak penerbit dilarang untuk memberikan fasilitas seperti BRI Protection Plus yang terdapat dalam formulir aplikasi kartu kredit BRI, apabila pemohon tidak menyetujui fasilitas yang ditawarkan tersebut. Jika BRI masih tetap memberikan fasilitas dan membebankan dampak tambahan biaya kepada Pemegang Kartu dan/atau memberikan fasilitas lain di luar fungsi utama Kartu Kredit maka dalam hal ini BRI dapat dikenakan sanksi, sesuai dengan pasal 38 ayat (1) PBI Nomor 14/2/PBI/2012 diatas.

\section{B. Pelaksanaan Hak dan Kewajiban Para Pihak Dalam Penggunaan Kartu Kredit Pada PT. Bank Rakyat Indonesia, Tbk. Cabang Padang.}

Berdasarkan wawancara dengan Ibu Prima salah satu staf bagian kartu kredit, dari dokumen perjanjian yang dibuat sendiri oleh BRI, dapat diketahui hak dan kewajiban masing-masing pihak dalam perjanjian kartu kreditnya yaitu :

1. Kewajiban Pemegang Kartu Kredit

a. Jika terjadi tunggakan pemegang kartu wajib melunasi seluruh tunggakannya

b. Pemegang wajib membayar semua tagihan minimum atas setiap tagihan rekening sesuai dengan ketentuan pembayaran yang ditentukan oleh BRI dari jumlah saldo baru ditambah tunggakan.

2. Hak pemegang kartu kredit

a. Pemegang kartu kredit yang namanya tercetak pada kartu kredit berhak menggunakan kartunya sebagai alat pembayaran kepada pedagang atau pengusaha yang menyatakan menerima pembayaran dengan kartu kredit, atau yang telah ditunjuk oleh penerbit kartu kredit.

b. Pemegang kartu kredit berhak memperoleh barang dan layanan jasa dari pedagang. 
c. Pemegang kartu kredit berhak untuk mengambil uang tunai pada bank di Indonesia maupun di luar negeri yang memasang logo kartunya selama masih dalam masa berlaku.

Adapun hak dan kewajiban dari BRI selaku penerbit kartu kredit adalah :

\section{Hak BRI}

a. Membebankan rekening Pemegang Kartu dengan biaya keterlambatan untuk setiap saldo bulanan yang tertunggak terhitung sesudah tanggal jatuh tempo, dan bunga yang berlaku saat itu, dihitung mulai tanggal transaksi dibukukan.

b. Tidak bertanggung jawab atas setiap cacat dan kekurangan dalam bentuk apapun atas barang atau jasa yang dibeli dan dibayar dengan menggunakan kartu. Dalam hal terjadi sengketa atas pembelian barang atau pembayaran jasa tersebut, Pemegang Kartu tetap wajib membayar tagihan Rekening.

c. Menagih kepada pemegang kartu tambahan atas faktur transaksi yang telah ditandatangani oleh pemegang kartu tambahan.

d. BRI berhak setiap saat mengurangi pagu kredit atas kartu, memblokir kartu, mengakhiri penggunaan kartu, dan mencabut semua hak yang melekat pada kartu.

e. Memblokir dan atau mendebet semua jenis rekening pemegang yang ada di BRI untuk keperluan pelunasan tagihan dan denda, bunga dan biaya-biaya lainnya ditanggung oleh pemegang.

2. Kewajiban BRI

BRI mempunyai kewajiban terhadap pemegang kartu kredit atas kartu kredit yang dikeluarkannya, yaitu menjamin pembayaran dengan menggunakan kartu kredit yang dilakukan oleh pemegang kartu kredit.

\section{Kendala-kendala Dalam Pelaksanaan Perjanjian Penggunaan Kartu} Kredit Serta Upaya Penyelesaiannya Pada PT. Bank Rakyat Indoesia, Tbk, Cabang Padang. 
Kendala-kendala yang dialami oleh pemegang kartu dapat terjadi kapan saja dan kendala tersebut antara lain, lamanya proses penerbitan kartu kredit, adanya tambahan biaya pada setiap transaksi tunai dan juga tambahan biaya ketika melakukan penggantian kartu. Dalam hal ini pemegang kartu kredit dapat meminta penyelesaian kepada bank penerbit sesuai dengan ketentuan-ketentuan yang telah disepakati sebelumnya. Pihak penerbit berkewajiban untuk menyelesaikan ataupun menerima pengaduan-pengaduan terhadap masalah yang diterima oleh nasabah khususnya pemegang kartu kredit.

Sesuai dengan ketentuan Bank Indonesia dalam PBI Nomor 10/10/PBI/2008 tentang penyelesaian pengaduan nasabah, terdapat dalam pasal 6 ayat (1) "Bank wajib menerima setiap Pengaduan yang diajukan oleh Nasabah dan atau Perwakilan Nasabah yang terkait dengan Transaksi Keuangan yang dilakukan oleh Nasabah." Serta pasal 7 ayat (1) "Penerimaan Pengaduan sebagaimana dimaksud dalam Pasal 6 dapat dilakukan pada setiap Kantor Bank dan tidak terbatas hanya pada Kantor Bank tempat Nasabah membuka rekening dan atau Kantor Bank tempat Nasabah melakukan Transaksi Keuangan.” Dan pasal 7 ayat (2) "Bank wajib memberikan penjelasan kepada Nasabah dan atau Perwakilan Nasabah mengenai kebijakan dan prosedur penyelesaian Pengaduan pada saat Nasabah dan atau Perwakilan Nasabah mengajukan Pengaduan.”

Apabila pihak Bank melanggar ketentuan pada pasal 6 dan 7 diatas, maka sanksi yang akan dikenakan sesuai dengan pasal 17, yaitu :

1. Bank yang melanggar ketentuan sebagaimana dimaksud dalam Pasal 2, Pasal 3, Pasal 4, Pasal 5, Pasal 6, Pasal 7 , Pasal 8, Pasal 9, Pasal 10, Pasal 11, Pasal 12, Pasal 13, Pasal 14, Pasal 15 dan Pasal 16 dikenakan sanksi administratif sesuai Pasal 52 Undang-Undang Nomor 7 Tahun 1992 tentang Perbankan sebagaimana telah diubah dengan UndangUndang Nomor 10 Tahun 1998 berupa teguran tertulis.

2. Pelanggaran sebagaimana dimaksud pada ayat 1 dapat diperhitungkan dengan komponen penilaian tingkat kesehatan Bank.

Apabila nasabah merasa tidak puas dengan hasil penyelesaian pengaduan yang dilakukan oleh pihak bank, maka perlu disediakan pula media yang dapat menampung penyelesaian sengketa antara nasabah dengan bank. Dan dikarenakan 
sebagian besar nasabah bank adalah nasabah kecil, maka media penyelesaian sengketa nasabah dengan pihak bank haruslah dapat memenuhi unsur sederhana, murah, dan cepat. ${ }^{6}$ Terdapat beberapa ketentuan dalam KUHPerdata tentang akibat hukum apabila pihak Bank atau debitur melakukan wanprestasi, yaitu : ${ }^{7}$

1. Pasal 1243 KUHPerdata "Debitur diwajibkan membayar ganti kerugian yang telah diderita oleh kreditur".

2. Pasal 1243 KUHPerdata "Apabila perikatan itu timbal balik, kreditur dapat menuntut pemutusan/ pembatalan perikatan melalui Hakim”.

3. Pasal 1237 (2) KUHPerdata "Dalam perikatan untuk memberikan sesuatu, resiko beralih kepada debitur sejak terjadi wanprestasi”.

4. Pasal 1267 KUHPerdata "Debitur diwajibkan memenuhi perikatan jika masih dapat dilakukan, atau pembatalan disertai pembayaran ganti kerugian".

5. Debitur wajib membayar biaya perkara jika diperkirakan di muka Pengadilan Negeri, dan debitur dinyatakan bersalah.

\section{PENUTUP}

\section{A. Kesimpulan}

Berdasarkan hasil penelitian dan pembahasan yang telah diuraikan pada bab sebelumnya, maka dapat diambil beberapa kesimpulan sebagai berikut :

1. Proses penerbitan kartu kredit pada BRI memerlukan waktu yang lama dan proses penerbitannya tidak dapat dilakukan di kantor cabang tetapi hanya dapat dilakukan di kantor pusat yaitu pada BRI Card Center yang ada di Jakarta.

2. Perjanjian baku yang dibuat sendiri oleh BRI tidak hanya menjelaskan hak dan kewajiban pemegang kartu kredit saja, tetapi juga menjelaskan hak dan kewajiban bank BRI sebagai bank penerbit. Hak dan kewajiban yang dibuat oleh BRI tidak memperhatikan asas keseimbangan dalam perjanjian. Hal tersebut dapat merugikan pemegang kartu dalam pelaksanaan penggunaan kartu kredit.

3. Kendala-kendala yang dihadapi oleh pihak penerbit yaitu BRI adalah pabila pemegang kartu lalai dalam penggunaan kartu kredit dan tidak

\footnotetext{
${ }^{6}$ Trias Palupi Kurnianingrum.Op Cit.,2008. Hlm.85.

${ }^{7}$ R.Subekti, Op., Cit., hlm. 204-205.
} 
melaksanakan kewajibannya dengan baik, maka penyelesaiannya pemegang kartu wajib memberikan penggantian biaya, rugi dan bunga yang telah ditentukan oleh pihak penerbit yaitu bank BRI cabang Padang. Selain kendala-kendala yang dialami oleh pihak penerbit diatas, terdapat juga kendala-kendala yang dialami oleh pemegang kartu.

\section{B. Saran}

Berdasarkan apa yang telah penulis teliti dalam penelitian ini, maka penulis mencoba memberikan saran dan masukan sebagai berikut:

1. Untuk bank penerbit agar dapat meminimalisasikan waktu dalam proses penerbitan meskipun harus diserahkan kepada BRI Card Center dan menjelaskan secara mendetail syarat-syarat dan ketentuan dalam mengajukan permohonan untuk menjadi pemegang kartu kredit.

2. Dalam pembuatan dokumen perjanjian kartu kredit, seharusnya penerbit memuat hak dan kewajiban para pihak secara seimbang dan tidak hanya memperbanyak hak dan kewajiban pihak pemegang kartu saja.

3. Disarankan kepada pihak penerbit yaitu BRI Cabang Padang agar menyelesaikan segala kendala-kendala yang menyangkut dalam pelaksanaan penggunaan kartu kredit oleh nasabah, serta menyelesaikan kendala tersebut secara cepat dan baik.

\section{DAFTAR PUSTAKA}

\section{BUKU}

Abdul Kadir Muhammad, Hukum Perikatan, PT. Citra Aditya, Bandung, 1992.

Abdulkadir Muhammad, Perjanjian Baku Dalam Praktek Perusahaan Perdagangan, Bandung: PT. Citra Aditya Bakti, 1992.

Amiruddin dan Zainal Asikin, Pengantar Metode Penelitian Hukum, PT. Raja Grafindo Persada, Jakarta, 2004 
Djoni S. Gazali, S.H.,M.Hum. dan Rachmadi Usman, S.H.,M.H, Hukum Perbankan, Sinar Grafika, Jakarta. 2010.

Johannes Ibrahim, "Kartu Kredit-Dilematis Antara Kontrak dan Kejahatan”, PT Refika Aditama, 2004, Bandung.

Kasmir S.E., Dasar-Dasar Perbankan, Jakarta, Rajawali Pers,2010

Kasmir, S.E. M.M.,Bank dan Lembaga Keuangan Lainnya,PT. Raja Grafindo Persada,Jakarta, 2008,

Marchelo, Media Indonesia, E-Money-“Dunia Menuju Tatanan Masyarakat Nontunai", kamis, 21 Februari 2013

Mariam Darus Badrulzaman, Kompilasi Hukum Perikatan, Citra Aditya Bakti, Bandung, 2001.

Munir Fuady,Hukum tentang Pembiayaan, Bandung : PT. Citra Aditya Bakti, 2006

R. Subekti, Hukum Perjanjian, Intermasa, Jakarta, 2002

R. Subekti dan R. Tjitrosudibio, Kitab Undang-undang Hukum Perdata, Jakarta : PT. Pradnya Paramita, 2004.

Salim H.S.,Hukum Kontrak: Teori dan Teknik Penyusunan, Sinar Grafika, Jakarta, 2003

Soerjono Soekanto, Pengantar Penelitian Hukum Jakarta,UI Press, 2006

Trias Palupi Kurnianingrum,"Perlindungan Nasabah Kartu Kredit Ditinjau Dari

UU No.8 Tahun 1999 Tentang Perlindungan Konsumen”. Universitas Diponegoro.2008.

Yahya Harahap, Segi-segi Hukum Perjanjian, Alumni, Bandung, 1986.

Zainudin Ali, Metode Penelitian Hukum, Sinar Grafika. Jakarta 2009

\section{PERATURAN PERUNDANG-UNDANGAN}

Kitab Undang-undang Hukum Perdata ( KUHPerdata)

Undang-Undang Republik Indonesia Nomor 7 tahun 1992 jo Undang-Undang Nomor 10 Tahun 1998 tentang Perbankan

Peraturan Bank Indonesia Nomor 10/10/PBI/2008 tentang perubahan atas PBI No 7/7/PBI/2005 Tentang Penyelesaian Pengaduan Nasabah 
Peraturan Bank Indonesia Nomor 14/2/PBI/2012 tentang perubahan atas PBI No 11/11PBI/2009 tentang Penyelanggaraan Kegiatan Alat Pembayaran Dengan Menggunakan Kartu (PBI APMK)

Undang-undang No. 8 Tahun 1999 Tentang Perlindungan Konsumen

\section{SITUS INTERNET}

http://www.gokartukredit.com

http://www.lawskripsi.com

https://ishfah7.wordpress.com/tag/istilah/

http://marantalawyer.com

http://www.creditcard-revolution.com

http://www.bri.co.id/articles/

http://www.irmadevita.com 